\title{
La influencia de los productos hidrofugantes en las modificaciones cromáticas del ladrillo cerámico
}

\section{The influence of water repellent products on the chromatic modifications of the ceramic brick}

\author{
J. A. Coronado Martín ${ }^{(*)}$, A. García Santos(*)
}

Recepción/Received: 17-II-10

Aceptación/Accepted: 26-IV-11

Publicado online/Online publishing: 14-VII-11

\section{RESUMEN}

Se analiza la variación cromática, color y luminosidad, que sufre el soporte cerámico protegido por la incorporación de un tratamiento con productos hidrofugantes.

Se propone una metodología nueva, basada en el modelo RGB donde se obtienen valores cuantificables de cada muestra cerámica mediante medición digital del color (histogramas de imagen), tomándose como base el mismo tipo de cerámica sin hidrofugar.

La variación cromática está determinada por el tipo de hidrofugante y por el material de base, obteniéndose los siguientes resultados:

- Todos los hidrofugantes estudiados producen variación en la tonalidad y luminosidad de la pieza.

- El ladrillo rojo inglés $(R)$ es el que presenta menor variación de luminosidad y tonalidad al ser tratado con hidrofugantes.

- El hidrofugante de componente siliconatos es el que menor variación cromática produce en dos de los tres ladrillos estudiados, tostado $(T)$ y rojo inglés $(R)$.

Palabras clave: ladrillo cerámico, polímero, propiedades superficiales, color, hidrofugantes.
SUMMARY

Chromatic variation, colour and luminosity, undergone by the ceramic support protected by the incorporation of a treatment with water repellent products, is analysed.

A new methodology is suggested, based on RGB model where quantifiable values from each ceramic sample are obtained through digital measurement of the colour (image histograms), taking as a base the same type of ceramics with no water repellents.

Chromatic variation is determined by the type of water repellent and the base material, obtaining the following results:

- All the water repellent studied cause variations in the shade and luminosity of the piece.

- English red brick $(R)$ is the one presenting less variation of luminosity and shade since it's been treated with water repellents.

- The water repellent of siliconates component is the one which causes less chromatic variation in two of the three bricks studied, the dark brown $(T)$ and the English red $(R)$ one.

Keywords: ceramic brick, polymeric materials, surface properties, colour, water repellents.

(*) Universidad Politécnica de Madrid (Madrid, España). 


\section{INTRODUCCIÓN}

La investigación analiza las modificaciones de la coloración de los ladrillos cerámicos cuando han sido tratados superficialmente con productos hidrofugantes teóricamente incoloros, determinando qué hidrofugante produce el menor cambio en las propiedades superficiales (color y luminosidad) de los ladrillos cerámicos.

Se identifican el mínimo número de tipos básicos de cerámica en relación con su proceso de fabricación: manual, extrusionado y prensado. Una vez establecida esa selección se identifican las características cromáticas de cada tipo básico de cerámica. Se obtiene para cada tipo básico de cerámica el producto hidrofugante que menos altera sus propiedades cromáticas. Se han analizado tres tipos de ladrillo en base a su proceso de fabricación, un ladrillo manual (M), otro extrusionado $(T)$ y otro prensado $(R)$.

Los productos hidrofugantes para esta investigación se estructuran en dos grandes grupos: orgánicos y órganosilícicos (Figura 1) (1).

Los estudiados en este artículo son los órgano-silícicos ya que en la actualidad son los más utilizados para la aplicación sobre materiales cerámicos porosos cara vista

\section{INTRODUCTION}

The research analyses the modifications in the colouring of the ceramic bricks when their surfaces have been treated with water repellent products theoretically colourless, determining which water repellent product causes the lesser change in the surface properties (colour and luminosity) of the ceramic bricks.

The minimum number of basic types of ceramics is identified relative to their production process: manual, extruded and pressed. Once that selection is established, the chromatic characteristics of each basic type of cerámics are identified. The water repellent product which less alters the chromatic properties of each basic type of ceramics is obtained. Three types of brick have been analysed based on their production process, a manual brick $(M)$, an extruded one $(T)$ and a pressed one $(R)$.

The water repellent products for this research are organised in two main groups: organics and organosilicic (Figure 1) (1).

The products studied in this article are the organosilicic ones since currently they are the most commonly used for application on porous ceramic face materials and

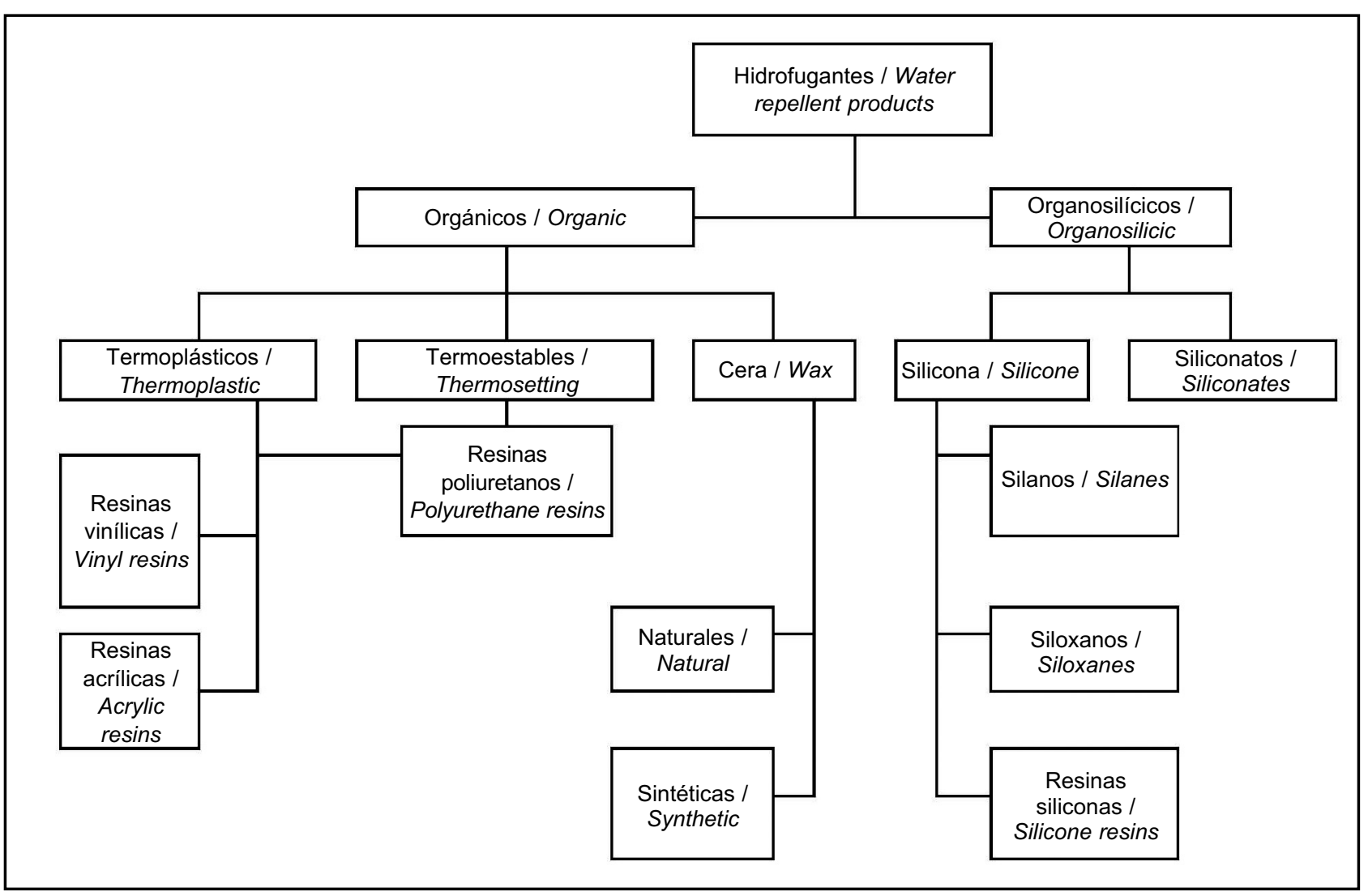

Figura 1. Clasificación de productos hidrofugantes.

Figure 1. Classification of water repellent products. 
y se pueden clasificar en: mono-componente y bi-componente:

1. Mono-componente: se obtienen a partir de un alquiltriclorosilano y son los siguientes:

- Siliconatos.

- Silanos.

- Siloxanos.

- Alquilalcoxisilanos oligoméricos.

- Alquilalcoxisilanos poliméricos.

- Resinas.

2. Bi-componente: se obtienen a partir de la mezcla de dos productos mono-componente.

Los productos hidrofugantes órgano-silícicos son una impregnación transparente y por lo tanto son elementos que penetran a través de la porosidad del material sobre el que se aplica. Esta penetración en los poros del material y la adherencia en su superficie modifican las propiedades superficiales del soporte, generando cambios en la percepción de las características del material cerámico (2).

Los trabajos de investigación publicados anteriormente que definen el estado de la cuestión con respecto al tema $(3,4)$ analizan las modificaciones de las propiedades superficiales, en cuanto a color, por la incorporación de materiales poliméricos en el material base, utilizando procedimiento digitales para su observación.

La normativa que regula la medición de color en superficie es la norma UNE-EN 15886 de enero de 2011, basada en el espacio de color CIE I*a*b*. En este artículo se propone una metodología nueva basada en la medición digital del color mediante los histogramas de imagen. Se usa el espacio de color RGB en el que cada color aparece descompuesto en función de sus tres componentes espectrales primarias de rojo, verde y azul.

\section{MATERIALES Y MÉTODOS}

\subsection{Fundamentos teóricos}

La adherencia entre una impregnación y la cerámica se debe a varios factores pero fundamentalmente a la diferencia de tensiones superficiales existentes entre ambos materiales. La composición de los hidrofugantes está basada en la utilización de materiales poliméricos que poseen una menor tensión superficial que el resto de los materiales utilizados en construcción y de esta manera garantizan su unión (5).

Los hidrofugantes órgano-silícicos son tratamientos teóricamente incoloros que forman una película continua they can be classified into: monocomponent and bicomponent:

1. Monocomponent: they are obtained from an alkytrichlorosilane and are the following:

- Siliconates.

- Silanes.

- Siloxanes.

- Oligomeric alkylalkoxysilanes.

- Polymeric alkylalkoxysilanes.

- Resins.

2. Bicomponent: they are obtained from the mixing of two monocomponent products.

Organosilicic water repellent products are a transparent impregnation and therefore are elements that penetrate through the porosity of the material on which they are applied. This penetration in the pores of the material and the adherence in its surface, modify the surface properties of the support, generating changes in the perception of the characteristics of the ceramic material (2).

The research works published previously defining the state of the art relative to the topic $(3,4)$, analyse the modifications of the surface properties, as for colour, by the incorporation of polymeric materials to the base material, using digital procedures for its observation.

The standard regulating the measurement of colour in surface is UNE-EN 15886 of January 2011, based on the CIE I*a*b* colour space. A new methodology is suggested in this article, based on the digital measurement of colour using image histograms. The colour space used is RGB, in which each colour appears split according to its three primary spectrum components, red, green and blue.

\section{MATERIALS AND METHODS}

\subsection{Theoretical Fundamentals}

The adherence strength between an impregnation and the ceramics is due to several factors but mainly to the difference of surface tensions which exists between both materials. The composition of the water repellent products is based on the use of polymeric materials having a lower surface tension than the rest of materials used in construction, guaranteeing this way their union (5).

Organosilicic water repellents are treatments theoretically colourless, which form a continuous film 
que recubre la superficie de los poros (Figura 2) y que reducen drásticamente la succión de agua, sin taponar los poros y, por tanto, sin alterar significativamente la permeabilidad del soporte a los gases y al vapor de agua. Es importante dejar claro que la hidrofugación reduce solo la succión, es decir, la velocidad con que el agua ocupa los capilares de la pieza, afectando mínimamente a la absorción de agua a largo plazo $(1,6)$.

El hidrofugante actúa adhiriéndose a las paredes de los poros del soporte. El producto aplicado influirá en la refracción de la luz incidente en el material provocando una variación del color original del material base.

Dado que existe una diferente casuística de tipos de polímeros utilizados por las diversas ofertas comerciales existentes, cada una de ellas poseerá una tensión superficial específica que interactuará de diferente modo con las bases sobre las que se aplique, con fenómenos de adherencia específicos, se degradará de modo diferente, sufrirá diversos fenómenos de envejecimiento, dando lugar a ensuciamientos específicos para cada tipo de polímero, y establecerá modificaciones en la percepción de las coloraciones que posea cada tipo de base sobre la que puedan aplicarse. El objeto de la presente investigación es analizar y observar la incidencia sobre bases cerámicas que producen las tipologías de polímeros utilizados según su composición.

\subsection{Ladrillos cerámicos}

En relación con los tipos de fabricación, la elección del material cerámico se realiza por medio de ladrillos. Se ha elegido una cerámica única, de la misma fábrica (Palau Sariñena, Sariñena, Huesca), de forma que todos los tipos de ladrillo elegidos tienen la misma arcilla, diferenciándose el proceso de fabricación. Se han analizado los siguientes tipos de ladrillo cara vista: which covers the pores' surface (Figure 2), and which drastically reduce the water suction, without blocking the pores, and therefore, without significantly altering the permeability of the support to gas and water vapor. It is important to make it quite clear that waterproofing with repellent products only reduces suction, that is the speed with which water fills the piece's capillaries, affecting minimally the water absorption in the long term $(1,6)$.

Water repellent products act by adhering to the walls of the pores of the support. The product applied will have an influence on the refraction of the light incident in the material, causing a variation of the original colour of the base material.

Since there is a casuistic difference of polymer types used by the several existing commercial offers, each of them will have a specific surface tension which will interact in a different way with the bases on which it will be applied, with specific adherence phenomena, will degrade in a different way, will undergo several aging phenomena, provoking specific foulings to each type of polymer, and will establish modifications in the perception of the colouring of each type of base on which it can be applied. The aim of the present research is to analyse and observe the incidence on ceramic bases caused by the polymer typologies used according to their composition.

\subsection{Ceramic bricks}

With regards to the types of production, the choice of the ceramic material is done by means of bricks. The same ceramics has been selected, from the same manufacture (Palau Sariñena, Sariñena, Huesca), so that all the brick types chosen have the same clay, but different production processes. The following face brick types have been analysed:

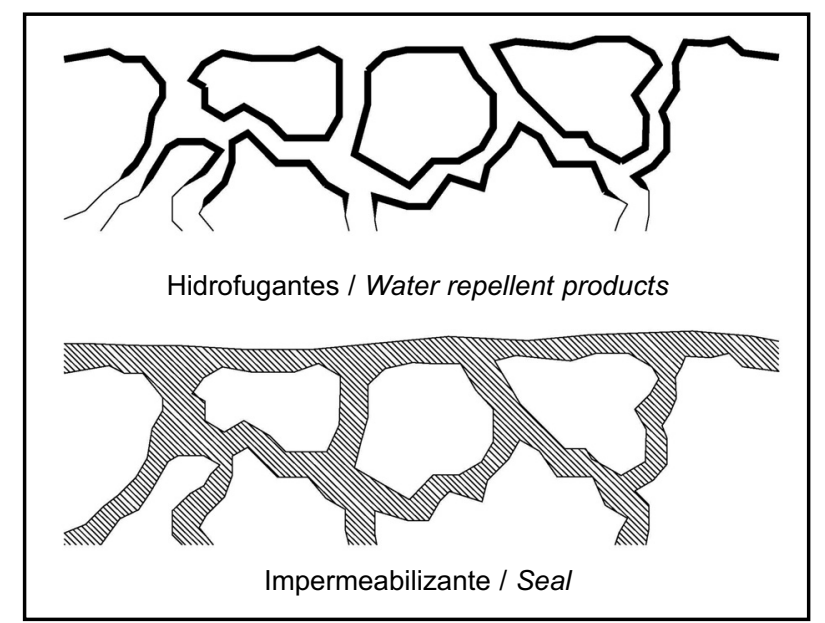

Figura 2. Diferencia entre el tratamiento con hidrofugantes y con impermeabilizantes. Figure 2. Difference between the treatment with water repellent products and seals. 
- Fabricación manual: ladrillo manual aragonés, denominado $M(7)$.

- Fabricación extrusionado: ladrillo tostado acabado tosco, denominado $\mathrm{T}$ (8).

- Fabricación prensado: ladrillo rojo inglés acabado tosco, denominado R (9).

Según la ficha técnica de los ladrillos y de acuerdo a la normativa vigente, los tres tipos de ladrillos analizados tienen las siguientes características: absorción de agua $\leq 10 \%$, succión $\leq 0,90 \mathrm{~g} / \mathrm{cm}^{2} x \mathrm{~min}$ y porcentaje de hue$\cos \leq 45 \%$, siendo su acabado superficial rugoso.

\subsection{Productos hidrofugantes}

En base a la clasificación indicada anteriormente, la selección de los productos hidrofugantes se realiza en función de su composición, con el fin de observar sobre las diferentes bases las modificaciones que cada uno de ellos puedan producir (Tabla 1).

\subsection{Metodología}

La metodología empleada está basada en trabajos previamente publicados $(3,4)$, donde se propone la utilización del software Photoshop como instrumento de observación y análisis del color. A partir de estas investigaciones realizadas sobre morteros de cemento se diseña un procedimiento de observación destinado a piezas cerámicas.
- Manual production: Aragonese manual brick, designated $M$ (7).

- Extruded production: Dark brown brick coarse finish, designated $T$ (8).

- Pressed production: English red brick coarse finish, designated $R$ (9).

According to the technical sheet of the bricks and to the applicable regulations, the three types of bricks analysed have the following characteristics: water absorption $\leq 10 \%$, suction $\leq 0.90 \mathrm{~g} / \mathrm{cm}^{2} x \min$ and voids content $\leq 45 \%$, its surface finish being rough.

\subsection{Water repellent products}

Based on the classification previously noted, the selection of the water repellent products is made according to their composition, with the aim to observe on the different bases the modifications that each one of them can cause (Table 1).

\subsection{Methodology}

The methodology used is based on previously published works $(3,4)$, where it is suggested touse the Photoshop software as am observation and colour analysis tool. An observation procedure destined to ceramic pieces is designed from these researches done on cement mortars.

Tabla 1 / Table 1

Selección y características de los productos hidrofugantes.

Selection and characteristics of the water repellent products.

\begin{tabular}{|c|c|c|c|c|c|c|c|}
\hline $\begin{array}{l}\text { Clasificación I } \\
\text { Clasification }\end{array}$ & $\begin{array}{c}\text { Hidrofugante } / \\
\text { Water } \\
\text { Repellent } n^{\circ}\end{array}$ & $\begin{array}{l}\text { Componente I } \\
\text { Component }\end{array}$ & $\begin{array}{l}\text { Solución I } \\
\text { Solution }\end{array}$ & $\begin{array}{l}\text { Acabado I } \\
\text { Finish }\end{array}$ & $\begin{array}{l}\text { Densidad } \\
\text { (kg/litro) / } \\
\text { Density } \\
\text { (kg/liter) }\end{array}$ & $\begin{array}{l}\text { Producto I } \\
\text { Product }\end{array}$ & $\begin{array}{c}\text { Empresa } \\
\text { comercializadora / } \\
\text { Trading Company }\end{array}$ \\
\hline \multirow{5}{*}{$\begin{array}{c}\text { Mono-componente I } \\
\text { Mono-component }\end{array}$} & 1 & Siliconatos / Siliconates & $\begin{array}{l}\text { Acuosa / } \\
\text { Aqueous }\end{array}$ & $\begin{array}{l}\text { Incoloro / } \\
\text { Colourless }\end{array}$ & 1.001 & Silicono & Teelax, S.A. \\
\hline & 2 & Silanos /Silanes & $\begin{array}{l}\text { Disolvente } \\
\text { (xileno) / } \\
\text { Solvent } \\
\text { (xylene) }\end{array}$ & $\begin{array}{l}\text { Incoloro / } \\
\text { Colourless }\end{array}$ & 0.8 & $\begin{array}{l}\text { Collak } \\
\text { Invisible }\end{array}$ & Collak, S.A. \\
\hline & 3 & $\begin{array}{c}\text { Siloxanos } \\
\text { oligoméricos / } \\
\text { Oligomeric siloxanes }\end{array}$ & $\begin{array}{c}\text { Disolvente } \\
\text { (white spirit*) / } \\
\text { Solvent } \\
\text { (white spirit*) }\end{array}$ & $\begin{array}{l}\text { Incoloro / } \\
\text { Colourless }\end{array}$ & 0.9 & Eurofilm HF & Eurotex \\
\hline & 4 & $\begin{array}{c}\text { Siloxanos poliméricos / } \\
\text { Polymeric sloxanes }\end{array}$ & $\begin{array}{c}\text { Disolvente } \\
\text { (white } \\
\text { spirit*) / } \\
\text { Solvent } \\
\text { (white spirit*) }\end{array}$ & $\begin{array}{l}\text { Incoloro / } \\
\text { Colourless }\end{array}$ & 0.83 & $\begin{array}{l}\text { Hidrofugante } \\
\text { Invisible }\end{array}$ & Pinturas Banaka \\
\hline & 5 & $\begin{array}{l}\text { Resina Fluorada / } \\
\text { Fluorinated Resin }\end{array}$ & $\begin{array}{l}\text { Acuosa / } \\
\text { Aqueous }\end{array}$ & $\begin{array}{l}\text { Incoloro / } \\
\text { Colourless }\end{array}$ & $0.95-1.00$ & $\begin{array}{c}\text { Flex } \\
\text { Oleofugo A }\end{array}$ & Pinturas Flexibles, S.L. \\
\hline $\begin{array}{l}\text { Bi-componente / } \\
\text { Bi-component }\end{array}$ & 6 & $\begin{array}{l}\text { Silanos-siloxanos / } \\
\text { Silanes-siloxanes }\end{array}$ & $\begin{array}{l}\text { Acuosa / } \\
\text { Aqueous }\end{array}$ & $\begin{array}{l}\text { Incoloro / } \\
\text { Colourless }\end{array}$ & 1.00 & $\begin{array}{c}\text { Thoro } \\
\text { Enviroseal B }\end{array}$ & $\begin{array}{l}\text { Basf Chemical } \\
\text { Company }\end{array}$ \\
\hline
\end{tabular}

* White Spirit: Hidrocarburo alifático derivado del petróleo / White Spirit: Aliphatic Hydrocarbon derived from petroleum. 
Se toman seis muestras de cada modelo de ladrillo elegido. La mitad de la cara vista de cada muestra es hidrofugada mediante brocha hasta saturación del soporte, según las recomendaciones de los fabricantes. El tiempo de secado de las muestras hidrofugadas es de un mínimo de 24 horas (el tiempo recomendado por los fabricantes para que el hidrofugante esté completamente seco). Tanto la hidrofugación de las muestras como el secado se realizan en condiciones ambientales de laboratorio.

Para la obtención de datos se utilizó una cámara Olimpus 400 digital, 4.0 megapíxel colocada en una mesa de reproducción, en la que, en su base se situaba la muestra de ladrillo a una distancia de $40 \mathrm{~cm}$ desde la cara vista hasta el objetivo de la cámara. La muestra se ilumina con cuatro lámparas de 75 vatios, obteniendo en la base de la mesa de reproducción, un valor de iluminancia de 760 lux, medido con luxometro digital marca Koban, modelo kl-6610 (Figura 3).

La toma de datos se realiza entre las 24 y las 72 horas después de la hidrofugación de las muestras. Se coloca la muestra de ladrillo en la mesa de reproducción estando la cara vista frente a la cámara fotográfica y esta es disparada mediante mando a distancia. El resultado es una imagen en la que se observa íntegramente la muestra presentada.

Esta imagen la llamamos imagen original y a través del programa informático PhotoShop CS4 se recorta una
Six samples of each chosen brick are taken. Half of the front face of each sample is waterproofed with water repellent products by brush until the support is saturated, according to the recommendations of the manufacturers. The drying time of the waterproofed samples is of at least 24 hours (the time recommended by the manufacturers for the water repellent product to be completely dry). Both the waterproofing with water repellent products and the drying are done in laboratory environmental conditions.

An Olympus 4004.0 megapixel digital camera, was used for the obtaining of the data, placed in a reproduction table, in whose base was placed the brick sample at a distance of $40 \mathrm{~cm}$ from the front face to the camera lens. The sample is lit with four 75 watts lamps, obtaining at the base of the reproduction table an illuminance value of 760 lux, measured with digital luxmeter of the brand koban, model kl-6610 (Figure 3).

The data gathering is done within 24 and 72 hours after the waterproofing with water repellent products of the samples. The brick sample is placed on the reproduction table with its front face facing the camera, which is shot by remote control. The result is an image in which the presented sample can be observed entirely.

We call this image original image and with the computer software PhotoShop CS4, a central part od the

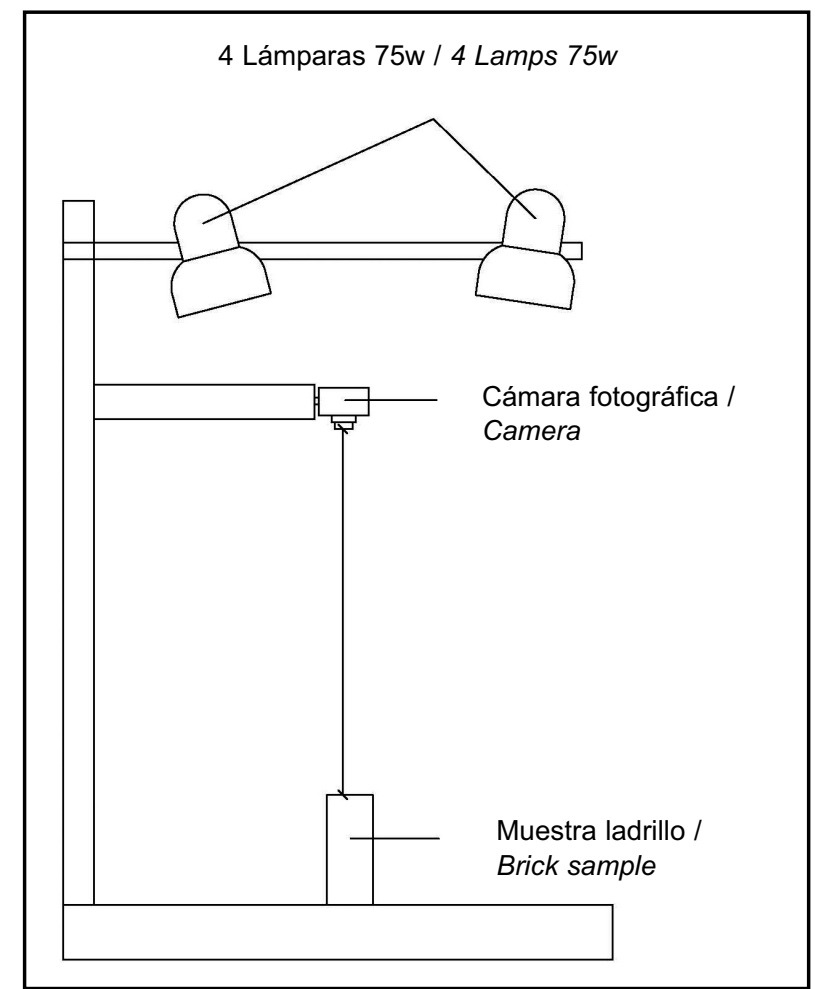

Figura 3. Esquema de mesa de reproducción para toma de muestras. Figure 3. Diagram of the reproduction table for sample taking. 
parte central de la zona hidrofugada y una zona central de la zona no hidrofugada, siendo estas últimas imágenes las que se analizan (Figura 4).

Para poder determinar, mediante medida física, el color de una determinada muestra, existen diferentes métodos basados en el empleo de colorímetros, foto colorímetros y espectrómetros, que determinan las coordenadas del color analizado, basándose en sistemas informáticos.

Para los ensayos que competen a esta investigación, se determinó la utilización del espacio de color RGB, que ofrece mayor independencia de dispositivos, pues los espacios de color no dependen de los monitores o las tintas (3). El RGB utiliza el rojo, verde y azul como colores primarios. Uno de los tres canales está en su valor máximo (255), y los otros dos están a cero.

Para previsualizar los valores de color y luminosidad se comprueban los histogramas de la imagen (Figura 5). El histograma de la imagen consiste en una gráfica de barras de 256 columnas que representan el número de pixeles de la imagen por cada valor de luminosidad, desde negro (0) a blanco (255). waterproofed zone and a central part of the nonwaterproofed zone are cut, being these images the ones which are analysed (Figure 4).

There are different methods tobe able to determine, through physical measurement, the colour of a certain sample, based on the use of colorimeters, photocolorimeters and spectrometers, which determine the coordinates of the analysed colour, based on computer systems.

For the tests incumbent on this research, the use of the $R G B$ colour space was determined, offering a higher independence of devices since the colour spaces do not depend on the monitors or the inks (3). RGB uses red, green and blue as primary colours. One of the three channels is at its higher value (255), and the other two at zero.

The image histograms (Figure 5) are checked to preview the colour and luminosity values. The image histogram consists of a bar graph with 256 columns which represent the number of pixels in the image for each luminosity value, from black (0) to white (255).

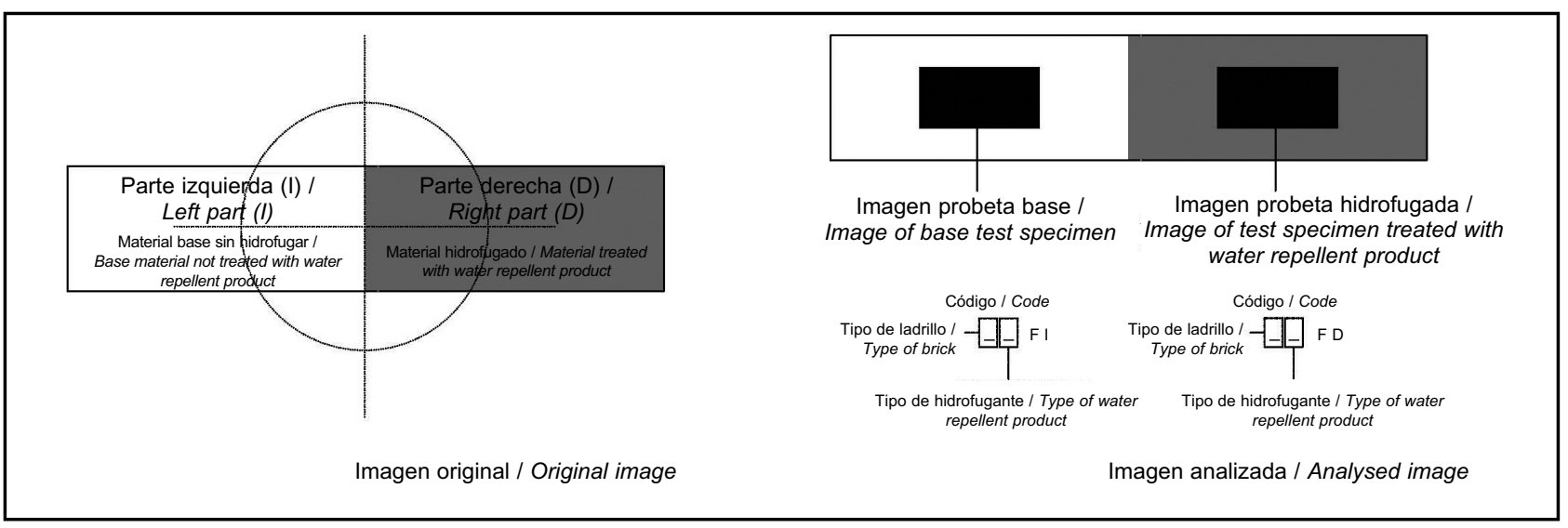

Figura 4. Esquema de toma de datos: imagen original y analizada.

Figure 4. Diagram of data gathering: original and analysed images.

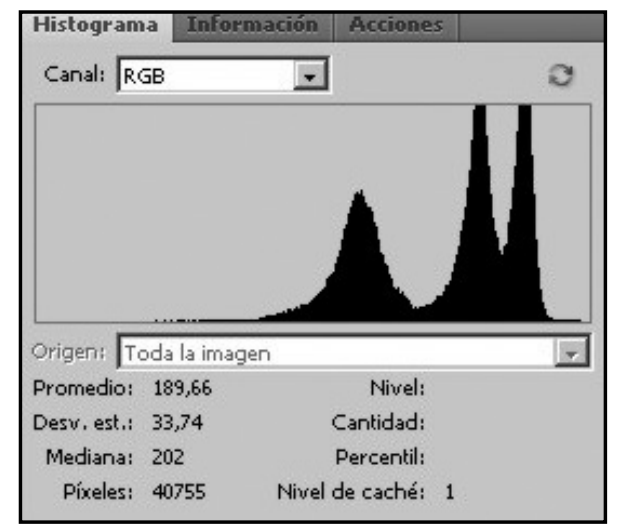

Figura 5. Histograma de una imagen.

Figure 5. Histogram of an image. 
En el eje horizontal se disponen las diferentes luminosidades divididas en 256 columnas, desde el negro (izquierda) hasta el blanco (derecha). La altura de cada una de las columnas determina el número de píxeles que hay por cada uno de los valores de luminosidad, el promedio (valor medio de luminosidad del conjunto de píxeles).

Las imágenes (probeta base y probeta hidrofugada) se analizan mediante los histogramas de imagen, obteniendo datos cuantificables de luminosidad, rojo, verde y azul (Figura 6).
The different luminosity are arranged in the horizontal axis divided in 256 columns, from the black (left) to the white (right). The height of each one of the columns determines the number of pixels for each of the luminosity values, the average (average luminosity value of the group of pixels).

The images (base test specimen and waterproofed test specimen) are analysed by means of image histograms, obtaining quantifiable data about luminosity, red, green and blue (Figure 6).

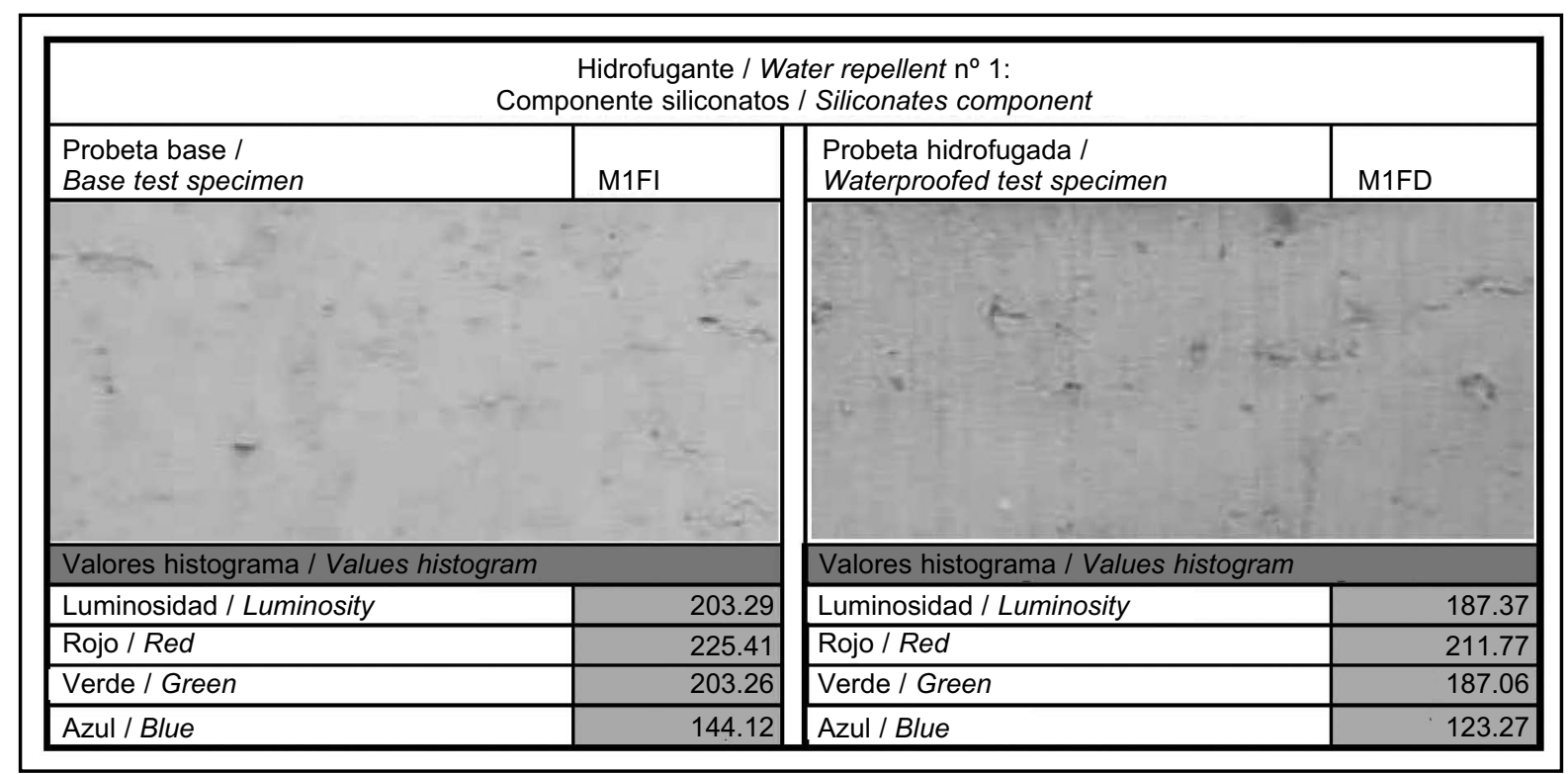

Figura 6. Imagen de probeta base e hidrofugada con sus valores de histograma.

Figure 6. Image of the base and waterproofed test specimens with their histogram values.

\section{RESULTADOS}

En las figuras que se presentan a continuación (Figuras $7,8,9$ y 10) se muestran gráficamente los valores obtenidos en cada medición de los histogramas de imagen. De cada uno de los espacios de color (rojo, verde y azul) y de la luminosidad, se representan los valores obtenidos de la cerámica tratada con cada tipo de hidrofugante (probeta hidrofugada) comparándolo con el valor de la cerámica sin hidrofugar (probeta base).

Para una lectura más clara de los resultados, se presenta la Tabla 2 donde se observan los valores reflejados en las Figuras 7, 8, 9 y 10 referentes a la luminosidad y a la descomposición cromática, establecidos porcentaje relativo, respecto a los valores iniciales de la cerámica sin hidrofugar, resaltando el valor con menor variación cromática (Tabla 2).

\section{RESULTS}

In the figures presented next (Figures 7, 8, 9 and 10), the values obtained in each measurement of the image histograms are represented graphically. The values obtained from the ceramics treated with each type of water repellent product (waterproofed test specimen) are represented for each of the colour spaces (red, green and blue), comparing them with the values of the non treated ceramics (base test specimen).

Table 2 is presented for a clearer interpretation of the results, with the values reflected in Figures 7, 8, 9 and 10 regarding luminosity and chromatic decomposition, established in relative percentage, with regard to the start values of the non waterproofed ceramics, highlighting the value with a lesser chromatic variation (Table 2). 
Tabla 2 / Table 2

Valores en porcentaje de desviación respecto a valores iniciales de la cerámica sin hidrofugar de luminosidad y descomposición cromática. Values in percent deviation relative to start values of the non waterproofed ceramics for brightness and chromatic decomposition.

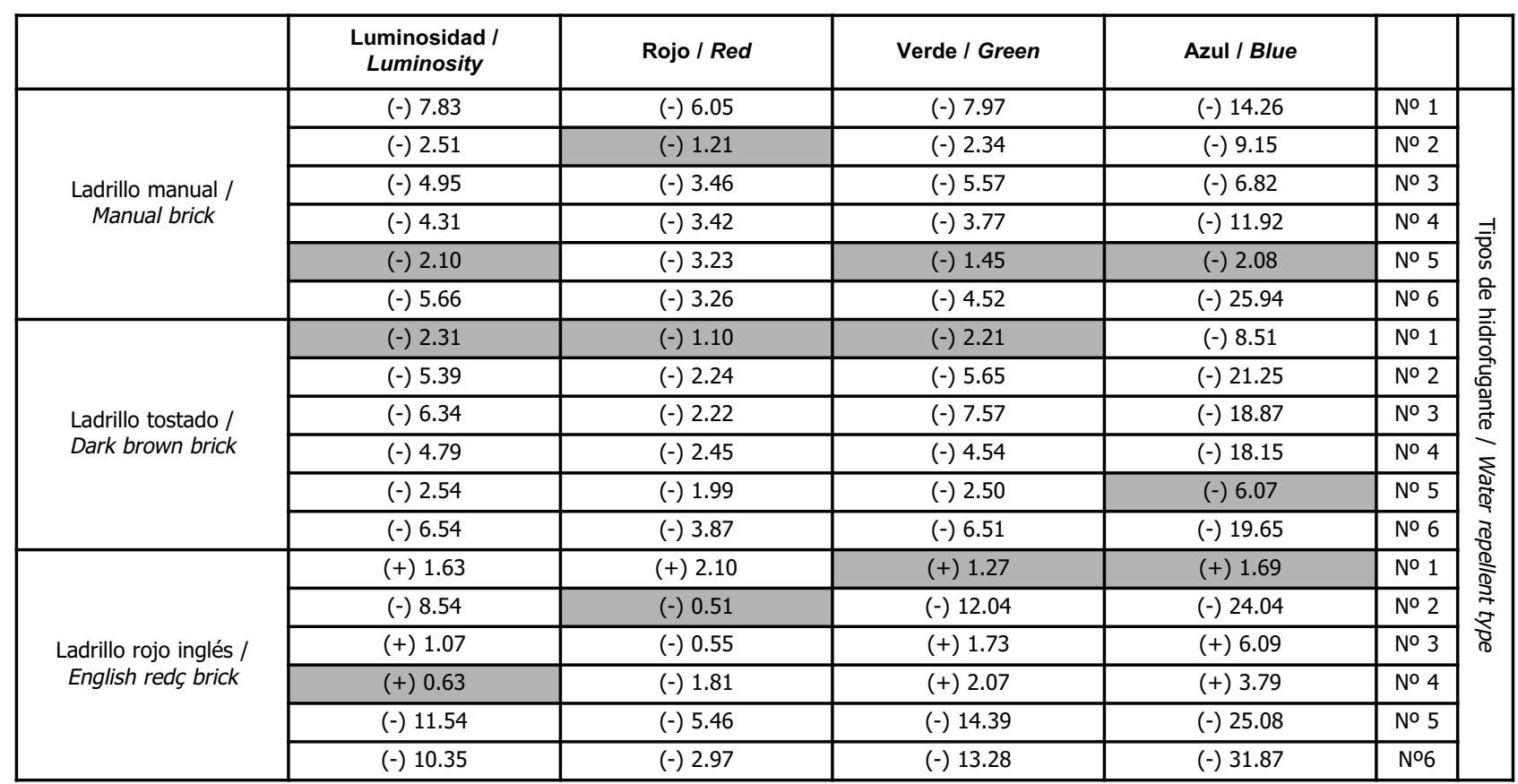

Con fondo gris se representa la menor variación de la probeta hidrofugada respecto de la base / The lesser variation of the waterproofed test specimen relative to the base test specimen is represented with a grey background.

El signo + determina que el valor absoluto obtenido en la medición de la pieza hidrofugada está por arriba del valor absoluto de la medición de la pieza cerámica base sin hidrofugar / The + sign determines that the absolute value obtained in the measurement of the waterproofed piece is above the absolute value of the measurement of the ceramic base piece not waterproofed.

El signo - determina que el valor absoluto obtenido en la medición de la pieza hidrofugada está por debajo del valor absoluto de la medición de la pieza cerámica base sin hidrofugar / The - sign determines that the absolute value obtained in the measurement of the waterproofed piece is below the absolute value of the measurement of the ceramic base piece not waterproofed.

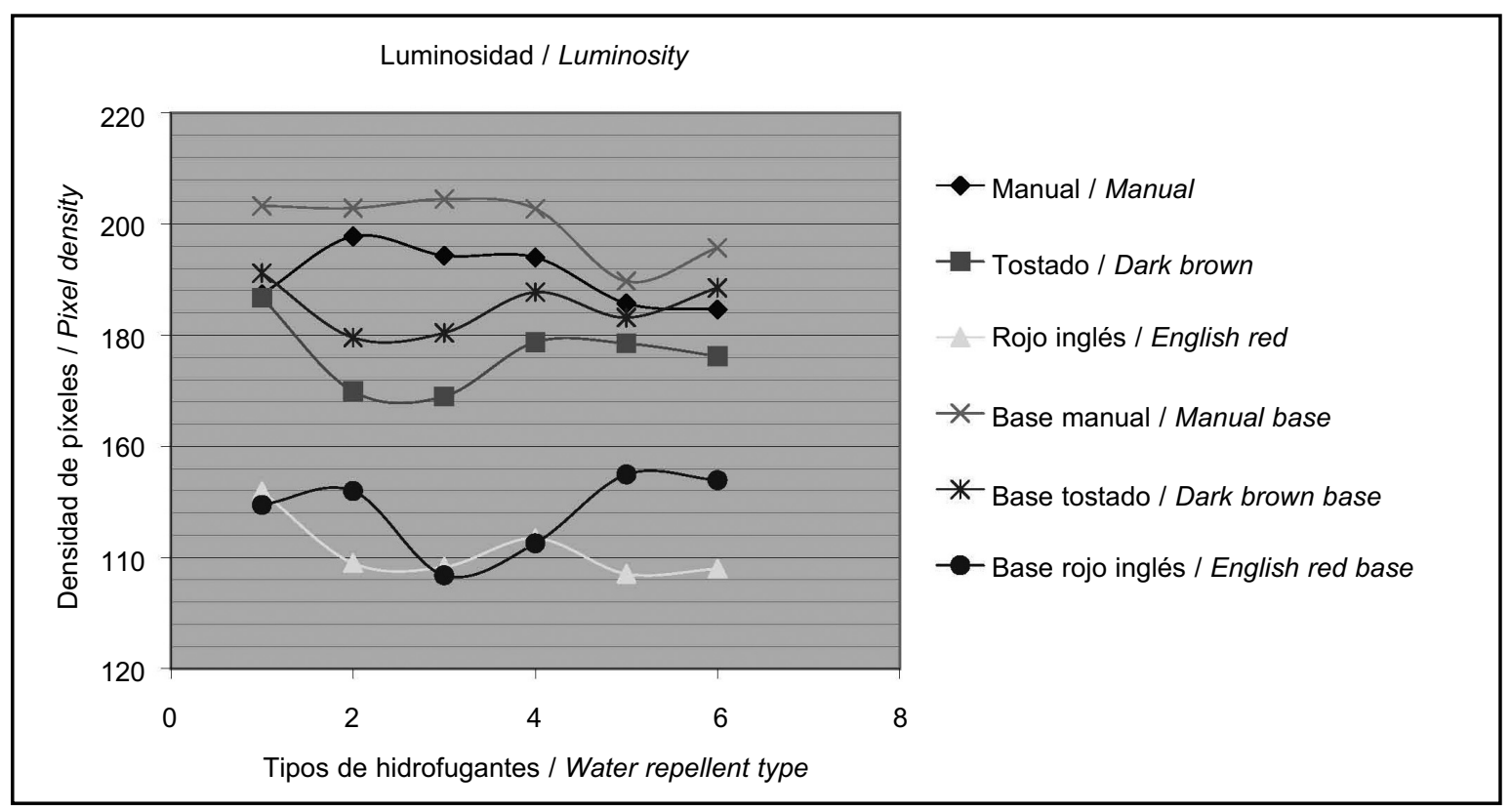

Figura 7. Luminosidad: comparativo entre valores de probeta base y probeta hidrofugada.

Figure 7. Luminosity: comparative between values of base test specimen and waterproofed test specimen. 


\section{DISCUSIÓN}

Todos los hidrofugantes producen variación en la tonalidad y brillo de la pieza, si bien pueden establecerse diferencias entre ellos de acuerdo al tipo de ladrillo y se mencionan a continuación:

- Los ladrillos manual (M) y tostado (T) tienden a tener el mismo comportamiento, se repiten los signos negativos (disminución) de los valores absolutos de cada uno de los tonos, en la mayoría de los hidrofugantes (cualquiera sea su constitución).

- Podríamos afirmar entonces que, sin importar el tipo de hidrofugante, la variación del tono se dará con las mismas características o parámetros de cuantificación en los dos tipos de ladrillos, denominados M y T, analizados en el trabajo.

El análisis general del color descompuesto en RGB en los tres tipos de ladrillo analizados (manual, tostado y rojo inglés) demuestra lo siguiente:

- De los tres espacios de color, rojo-verde-azul, el azul es el que varía con mayor valor absoluto. El rojo es el que menor variación tiene y varía siempre con signo negativo o en disminución. El espacio verde varía entre los valores de rojo y azul de manera irregular.

- Por lo expuesto podemos afirmar que la apreciación del color en la cerámica tratada con productos hidrofugantes modifica su tonalidad, tendiendo hacia los tonos llamados "cálidos", por la presencia del rojo y pérdida del azul.

\section{DISCUSSION}

All the water repellent products cause variation in the shade and luminosity of the piece, although differences can be established between them according to the brick type, which are mentioned next:

- Manual (M) and tanned (T) bricks, tend to have the same behaviour, the negative signs (decrease) of the absolute values of each one of the shades are repeated, in most of the water repellent products (whichever their constitution may be).

- We could then state that, without taking into account the type of water repellent product, the variation of shade will take place with the same characteristics or quantification parameters in both types of bricks, designed $M$ and $T$, analysed in this work.

The general analysis of the colour decomposed into RGB in the three types of brick analysed (manual, tanned and English red) proves the following:

- Out of the three colour spaces, red-green-blue, the blue one is the one which varies with a higher absolute value. The red one is the one which has a lesser variation and always varies with a negative sign or decreasing. The green space varies between the red and blue values in an irregular way.

- In light of the aforementioned we can state that the appreciation of the colour in the ceramics treated with water repellent products modifies its shade, tending to the shades called "warm", because of the presence of red and the loss of blue.

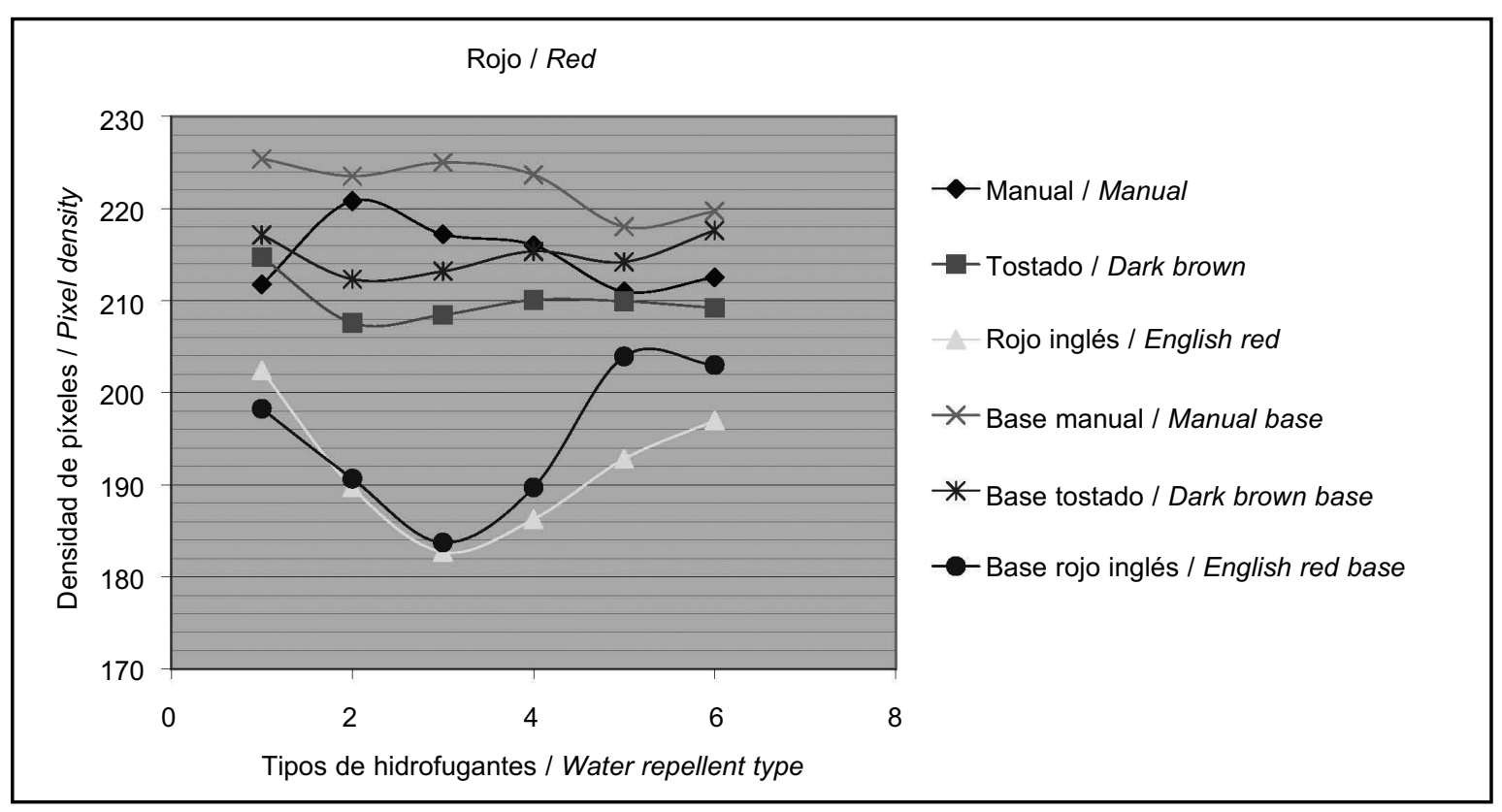

Figura 8. Rojo: comparativo entre valores de probeta base y probeta hidrofugada.

Figure 8. Red: comparative between values of base test specimen and waterproofed test specimen. 
- Por lo general, al aplicar producto hidrofugante los espacios de color, rojo-verde-azul, varían con signo negativo (disminución), excepto en el ladrillo rojo inglés $(R)$ que con la aplicación de los hidrofugantes números 1,3 y 4 su variación es de signo positivo (aumento).

- La luminosidad sigue el mismo comportamiento que los espacios de color, varía con signo negativo (disminución), excepto en el ladrillo rojo inglés ( $R$ ) que con la aplicación de los hidrofugantes números 1,3 y 4 varían con signo positivo (aumento).

Se detectan tres factores clave en el comportamiento de las tipos de ladrillo, en relación con su proceso de fabricación y con el tipo de hidrofugante utilizado:

- Los valores RGB del material base: los ladrillos manual (M) y extrusionado ( $T$ ) se incluyen en la misma clasificación cromática (rango de valores $\mathrm{R} 230$ 200, G 200-170, B 140-110), diferente de la clasificación cromática del ladrillo prensado (rango de valores R 200-170, G 140-110, B 110-80). Esta propiedad cromática del material base produce un resultado similar al hidrofugar los ladrillos manual (M) y extrusionado $(T)$, y resultado distinto en el ladrillo prensado (R).

- El acabado superficial del material base: se observa que la influencia de la rugosidad del material base en el material tratado no influye en el resultado final, ya que los tres tipos de ladrillo tienen acabado rugoso y el ladrillo manual (M) y extrusionado ( $\mathrm{T}$ ) presentan comportamiento distinto al ladrillo prensado $(R)$.
- In general, when applying the water repellent product the colour spaces, red-green-blue, vary with a negative sign (decrease), except for the English red brick $(R)$, whose variation is of a positive sign (increase) with the application of water repellent products no 1,3 and 4.

- The luminosity follows the same behaviour that the colour spaces, varies with a negative sign (decrease), except for the English red brick $(R)$, whose variation is of a positive sign (increase) with the application of water repellent products $n^{0} 1,3$ and 4.

Three key factors in the behaviour of the brick trypes are detected with regards to their production process and with the type of water repellent product used:

- The RGB values of the base material: manual (M) and extruded $(T)$ bricks are included in the same chromatic classification (range of values $R$ 230-200, G 200-170, B 140-110), different to the chromatic classification of the pressed brick (range of values $R$ 200-170, G 140-110, B 110-80). This chromatic property of the base material causes a similar result when waterproofing with water repellent products the manual $(M)$ and extruded $(T)$ bricks, and a different result in the pressed $(R)$ brick.

- The surface finish of the base material: as observed, the influence of the roughness of the base material in the treated material does not have an influence in the final result, since the three types of brick have a rough finish and the manual $(M)$ and extruded $(T)$ bricks present a different behaviour than that of the pressed $(R)$ brick.

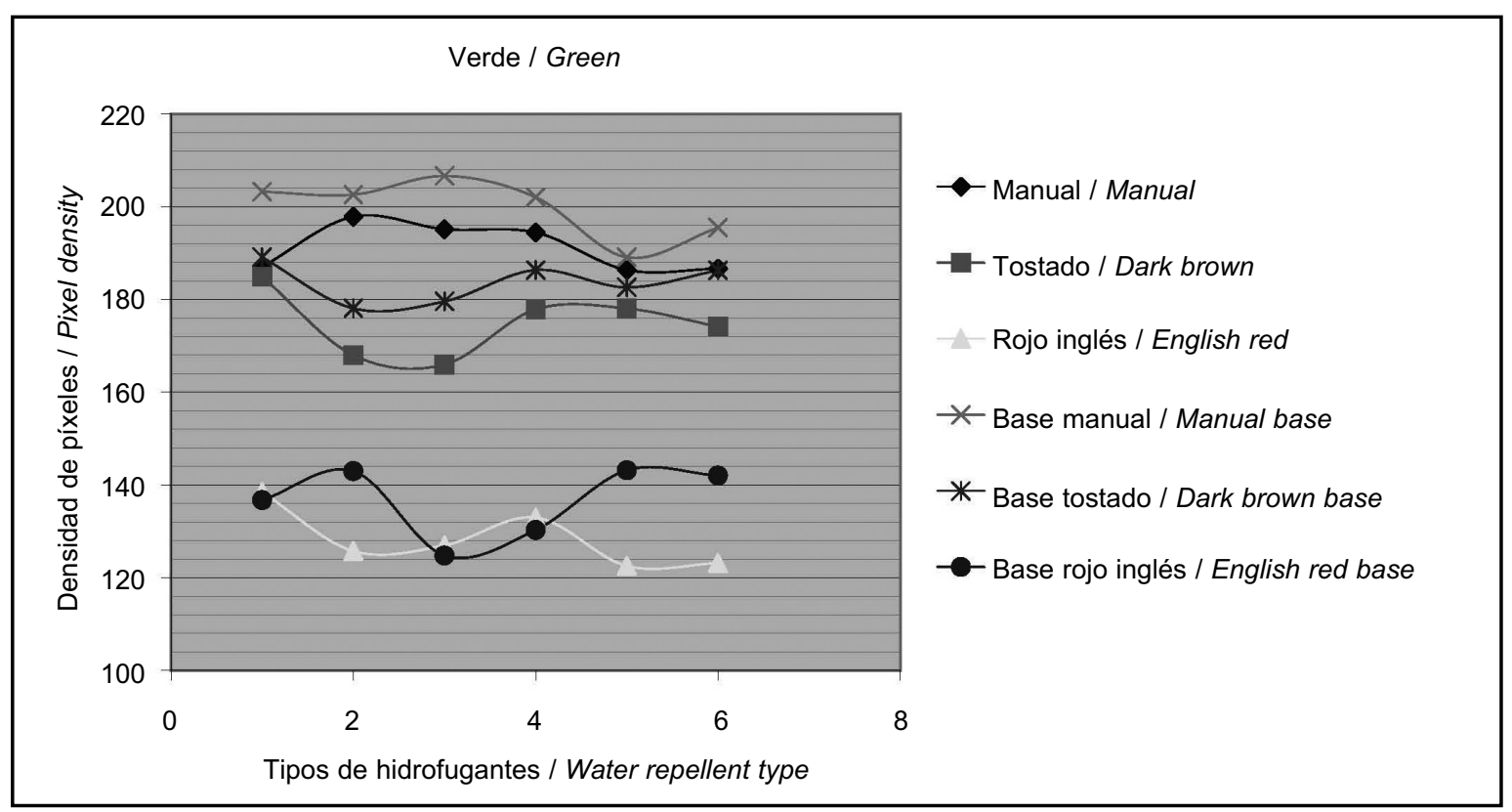

Figura 9. Verde: comparativo entre valores de probeta base y probeta hidrofugada.

Figure 9. Green: comparative between values of base test specimen and waterproofed test specimen. 
- La porosidad del material base: durante el proceso de transformación de la arcilla en cerámica se produce una reducción de agua. Dependiendo del tipo de fabricación (manual, extrusionado o prensado), la cerámica resultante será más o menos compacta, existiendo un gradiente de compacidad entre el ladrillo manual (M), el extrusionado $(T)$ y el prensado $(R)$. Se observa que los tipos manual (M) y extrusionado ( $\mathrm{T}$ ) tienen el mismo comportamiento, distinto del tipo prensado (R).

Se analiza como influye cada tipo de hidrofugante en cada uno de los espacios de color y en la luminosidad de los tipos de ladrillos estudiados:

\section{Hidrofugante $n^{\circ} 1$ : siliconatos}

La luminosidad y los espacios rojo, verde y azul sufren una variación negativa en el ladrillo manual y tostado, siendo de mayor proporción en el ladrillo manual. La variación en el ladrillo rojo inglés es positiva.

El hidrofugante a base de siliconatos produce mayor variación de tonalidad y luminosidad en el ladrillo manual. La variación es negativa en el ladrillo manual y en el tostado y positiva en el rojo inglés con valores pequeños.

\section{Hidrofugante $n^{\circ} 2$ : silanos}

En los tres tipos de cerámica se produce una disminución de la luminosidad y de los espacios verde y azul, presentando un mayor valor absoluto en el rojo inglés.
- The porosity of the base material: a reduction of water takes place during the transformation process of the clay into. Depending on the production type (manual, extruded or pressed) the resulting ceramics will be more or less compact, a compactness gradient existing between the manual $(M)$, extruded $(T)$ and pressed ( $R$ ) bricks. As observed, the manual (M) and extruded $(T)$ types have the same behaviour, different to the pressed $(R)$ one.

The influence of each type of water repellent product in each one of the colour spaces and in the luminosity of the types of bricks studied is analysed.

\section{Water Repellent Product $n^{\circ}$ 1: siliconates}

The luminosity and the red, green and blue spaces undergo a negative variation in the manual and tanned bricks, the one in the manual brick being of a higher proportion. The variation in the English red brick is positive.

The siliconates-based water repellent causes a higher variation of shade and luminosity in the manual brick. The variation is negative in the manual and tanned bricks and positive in the English red brick with small values.

\section{Water Repellent Product $n^{\circ} 2$ : silanes}

There is a decrease of the luminosity and the green and blue spaces in the three types of ceramics, presenting a higher absolute value in the English red.

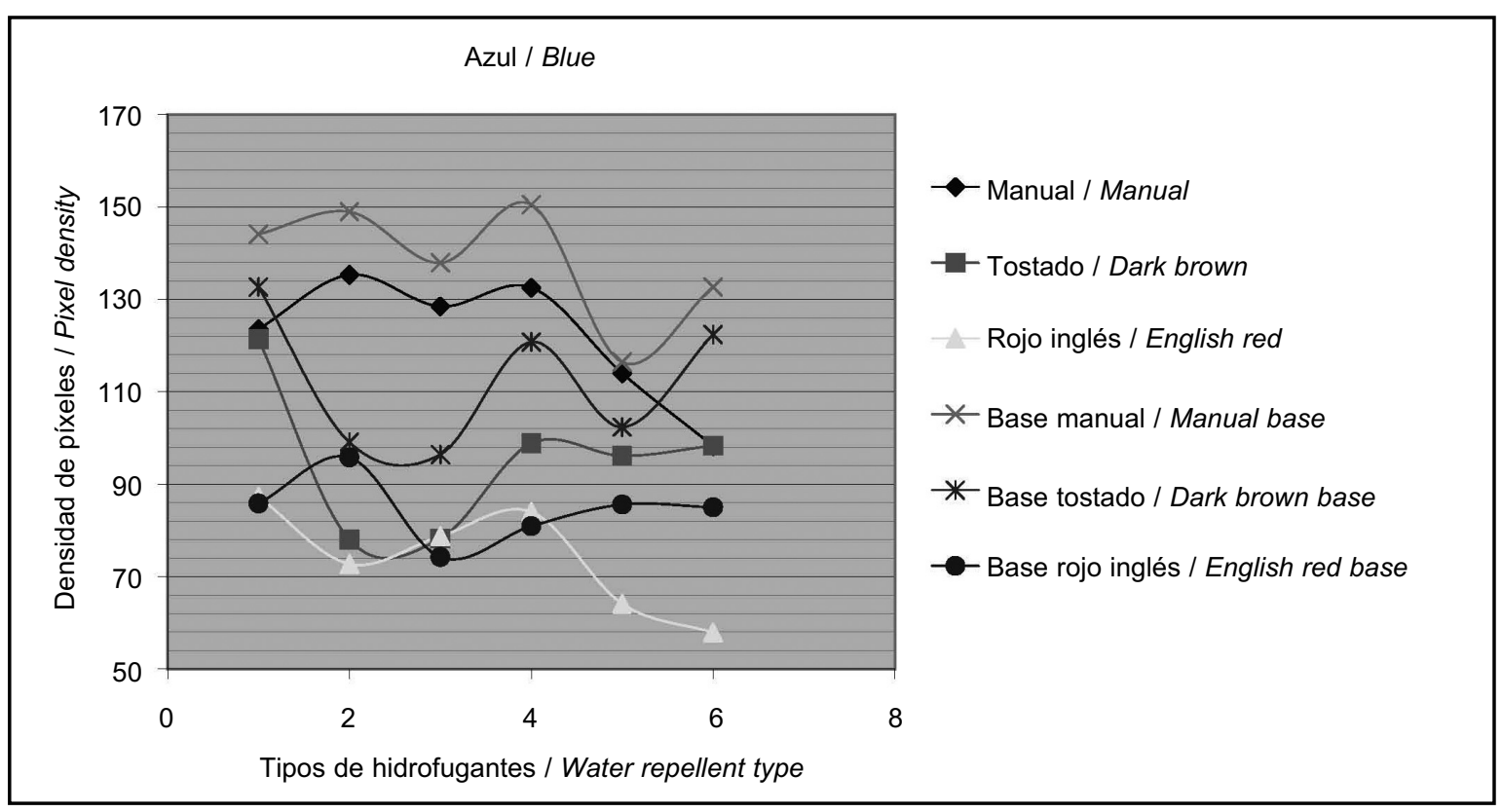

Figura 10. Azul: comparativo entre valores de probeta base y probeta hidrofugada.

Figure 10. Blue: comparative between values of base test specimen and waterproofed test specimen. 
El espacio rojo apenas disminuye en el rojo inglés, disminuyendo en mayor grado en el ladrillo tostado.

Se puede observar que el hidrofugante a base de silanos produce disminución de tonalidad y luminosidad en los tres tipos de ladrillo, apreciándose mayor variación en el rojo inglés.

\section{Hidrofugante $n^{0} 3$ : siloxanos oligoméricos}

La luminosidad y los espacios verde y azul sufren una variación negativa en el ladrillo manual y tostado, y de valor semejante y una variación positiva en el ladrillo rojo inglés.

El espacio rojo disminuye en los tres tipos de ladrillo, produciéndose la mayor disminución en el manual, siendo la del rojo inglés de valor muy pequeño.

Se observa que el hidrofugante a base de siloxanos oligoméricos produce disminución de tonalidad y luminosidad en el ladrillo manual y tostado, apreciándose mayor variación en el tostado, y un pequeño aumento de los valores en el rojo inglés.

\section{Hidrofugante $n^{\circ} 4$ : siloxanos poliméricos}

La luminosidad disminuye con valores prácticamente iguales en el ladrillo manual y tostado, y aumenta con un valor prácticamente despreciable en el rojo inglés.

El espacio rojo disminuye en los tres tipos de ladrillo, produciéndose la mayor disminución en el ladrillo manual.

Los espacios verde y azul sufren una variación negativa de valor semejante en el ladrillo manual y tostado, siendo mayor la de este último, y una variación positiva en el ladrillo rojo inglés.

El hidrofugante a base de siloxanos poliméricos produce disminución de tonalidad y luminosidad en el ladrillo manual y tostado, apreciándose mayor variación en el tostado, y pequeño aumento de los valores en el rojo inglés.

\section{Hidrofugante $n^{\circ} 5$ : resina fluorada}

La luminosidad disminuye en los tres tipos de ladrillos, produciéndose la mayor disminución en el rojo inglés.

Los espacios rojo, verde y azul, al igual que la luminosidad, sufren una variación negativa en los tres tipos de ladrillos, siendo el mayor valor el del ladrillo rojo inglés.

Se puede observar que el hidrofugante a base de resina fluorada produce disminución de tonalidad y luminosidad
The red space barely decreases in the English red, decreasing more in the tanned brick.

As observed, the silanes-based water repellent causes a decrease in shade and luminosity in the three types of brick, with a greater variation visible in the English red.

\section{Water Repellent Product $n^{\circ}$ 3: oligomeric siloxanes}

The luminosity and the green and blue spaces undergo a negative variation in the manual and tanned bricks, and similar in value, and a positive variation in the English red brick.

The red space decreases in the three types of brick, the one in the manual brick being the higher, and the one in the English red brick being of a very small value.

As observed, the oligoremic siloxanes-based water repellent causes a decrease in shade and luminosity in the manual and tanned bricks, with a greater variation in the tanned one, and a small increase of the values in the English red brick.

\section{Water Repellent Product $n^{\circ}$ 4: polymeric siloxanes}

The luminosity decreases with practically the same values in the manual and tanned bricks, and increases with a practically negligible value in the English red brick.

The red space decreases in the three types of brick, the one in the manual brick being the higher.

The green and blue spaces undergo a negative variation of a similar value in the manual and tanned bricks, the latter being higher, and apositive variation in the English red brick.

The polymeric siloxanes-based water repellent causes a decrease in shade and luminosity in the manual and tanned brick, with a greater variation visible in the tanned one, and a small increase of the values in the English red brick.

\section{Water Repellent Product $n^{\circ}$ 5: Fluorinated Resin}

The luminosity decreases in the three types of bricks, the greater decrease taking place in the English red one.

The red, green and blue spaces, as well as the luminosity, undergo a negative variation in the three types of bricks, the greater value being that of the English red brick.

As observed, the fluorinated resin-based water repellent causes a decrease in shade and luminosity in the three 
en los tres tipos de ladrillo, apreciándose mayor variación en el rojo inglés.

\section{Hidrofugante $n^{\circ}$ 6: silanos/siloxanos}

La luminosidad y el espacio de color verde disminuyen en los tres tipos de ladrillos, produciéndose la mayor disminución en el rojo inglés.

El espacio rojo disminuye en los tres tipos de ladrillo con valores semejantes, produciéndose la mayor disminución en el ladrillo tostado.

El espacio azul disminuye en los tres tipos de ladrillo, produciéndose la mayor disminución en el ladrillo manual.

El hidrofugante a base de silanos/siloxanos produce disminución de tonalidad y luminosidad en los tres tipos de ladrillos, siendo estas variaciones desiguales de los espacios de color entre los tres tipos de cerámica, indistintamente de cuál sea su característica (manual, tostado o rojo inglés).

\section{CONCLUSIONES}

La superficie de las piezas cerámicas de fachada tratadas con productos hidrofugantes adoptan tonos distintos a los originales de la pieza sin hidrofugar. Esta variación está determinada por el tipo de hidrofugante, pero fundamentalmente de acuerdo al material de base.

\subsection{Sobre el material cerámico}

Los resultados respecto al material base nos permiten sugerir que para superficies de fachadas construidas con piezas cerámicas, que debieran tratarse con productos hidrofugantes, es recomendable la elección de ladrillo prensado $(R)$, ya que en este tipo de ladrillo las variaciones de luminosidad y tonalidad son, en general, de valores mas bajos que en los otros tipos de ladrillo (manual y tostado).

\subsection{Sobre los productos hidrofugantes}

Los resultados respecto a los productos hidrofugantes nos permite sugerir que para superficies de fachadas construidas con piezas cerámicas que deban tratarse con productos hidrofugantes, y en las cuales ya está determinado el tipo de cerámica, es recomendable la elección de:

- Hidrofugante de componente resina fluorada para ladrillos del tipo manual (M), ya que corresponde al producto que produce menor variación del valor absoluto de la medición del color, en tres de sus cuatro componentes. types of brick, with a greater variation visible in the English red one.

\section{Water Repellent Product $n^{\circ}$ 6: silanes/siloxanes}

The luminosity and the green space colour decrease in the three types of bricks, the greater decrease taking place in the English red.

The red space decreases in the three types of brick with similar values, the greater decrease taking place in the tanned brick.

The blue space decreases in the three types of brick, the greater decrease taking place in the manual brick.

The silanes/siloxanes-based water repellent causes a decrease in shade and luminosity in the three types of bricks, these variations being different from the colour spaces between the three types of ceramics, regardless of their characteristic (manual, tanned or English red).

\section{CONCLUSIONS}

The surface of the façade ceramic pieces treated with water repellent products take different shades to the original ones in the pieces with no waterproofing treatment. This variation is determined by the type of water repellent product, but essentially according to the base material.

\subsection{About the ceramic material}

The results with regards to the base material allow us to suggest that for façades surfaces built with ceramic pieces which should be treated with water repellent products, the choice of pressed ( $R$ ) brick is recommended, since in this type of brick the luminosity and shade are, in general, of lower values than in the other types of brick (manual and tanned).

\subsection{About the water repellent products}

The results with regards to the water repellent products allow us to suggest that for façades surfaces built with ceramic pieces which should be treated with water repellent products, and for which the ceramic type is already determined, the recommended choice is:

- Water repellent product of fluorinated resin component for manual (M) bricks, since it's the product that causes the lowest variation of the absolute value of the colour measurement, in three out of its four components. 
- Hidrofugante de componente siliconatos para los ladrillos industrializados, extrusionados $(T)$ y prensados $(R)$, ya que corresponde al producto que produce menor variación del valor absoluto de la medición del color, en tres y en dos de sus cuatro componentes, en cerámica extrusionada y prensada, respectivamente.
- Water repellent product of siliconates component for industrialized, extruded $(T)$ and pressed $(R)$ bricks, since it's the product that causes the lowest variation of the absolute value of the colour measurement, in three and in two out of its four components, in extruded and pressed ceramics respectively.

\section{BIBLIOGRAFIA / BIBLIOGRAPHY}

(1) Pérez Monserrat, E.; Gómez Heras, M.; Álvarez de Buergo, M.; Fort González, R.: "Polímeros sintéticos para la conservación de materiales pétreos", Ciencia, Tecnología y Sociedad para una conservación sostenible del patrimonio pétreo (2007), pp. 71-83. Departamento de Publicaciones Universidad Popular José Hierro, San Sebastián de los Reyes. 71-82. ISBN: 84-95710-41-2.

(2) Horie, C. V.: "Materials for conservation: organic consolidants, adhesives and coatings", Editorial Butterworth (1987).

(3) García Santos A.; Conci Rinaudo M.: "Variación del color del soporte cerámico tratado con pintura antigraffiti", Mater. Construcc., vol. 55, no 278 (abril/mayo/junio de 2005), CSIC, pp. 55-68.

(4) Beltramone, A.; García Cruz, A.; García Santos A.: "Modificaciones de las propiedades superficiales en el hormigón visto, por la utilización de diferentes tipos de desencofrantes y aditivos plásticos", Mater Construcc., vol 53, n 270 (abril/mayo/junio de 2003), CSIC, pp. 71-78.

(5) García Santos, A.: "Los plásticos en la construcción I y II", Cuadernos del Instituto Juan Herrera, Escuela Técnica Superior de Arquitectura (2001), pp 27-42, Madrid.

(6) Wacker-chemie Gmbh: "Procedimiento para hidrofugar superficies de materiales de construcción", patente de invención (1973).

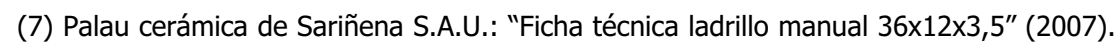

(8) Palau cerámica de Sariñena S.A.U.: "Ficha técnica ladrillo tostado tosco 3×29" (2007).

(9) Palau cerámica de Sariñena S.A.U.: "Ficha técnica ladrillo rojo inglés tosco 3×29" (2007). 